\title{
Thiamine refractory Wernickes encephalopathy reversed with magnesium therapy
}

\author{
John Joseph Coughlan, Thomas Mross, Meghan Wafer, Richard Liston
}

Department of Medicine, University Hospital Kerry,

Tralee, Ireland

\section{Correspondence to} Dr John Joseph Coughlan, jicough|@gmail.com

Accepted 12 October 2016

CrossMark

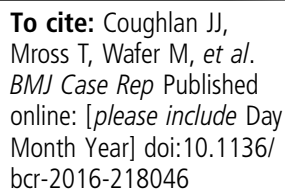

\section{DESCRIPTION}

A 34-year-old man was presented to our emergency department in alcohol withdrawal.

Despite initial treatment with high-dose intravenous thiamine therapy he went on to develop nystagmus (video 1), ataxia, pass pointing, intention tremor and worsening confusion. He was diagnosed with Wernickes encephalopathy, an acute neuropsychiatric syndrome resulting from thiamine deficiency. ${ }^{1}$

His serum magnesium levels were found to be low at $0.41 \mathrm{mmol} / \mathrm{L}$ (normal range $0.66-1.02 \mathrm{mmol} / \mathrm{L}$ ). He was started on high-dose intravenous magnesium in addition to thiamine replacement and his neurological symptoms resolved once his serum magnesium levels had normalised (video 2).

He was discharged home and on review in clinic 4 weeks later, he had made a complete recovery.

Magnesium is an essential cofactor of an enzyme in the pentose phosphate pathway, transketolase,

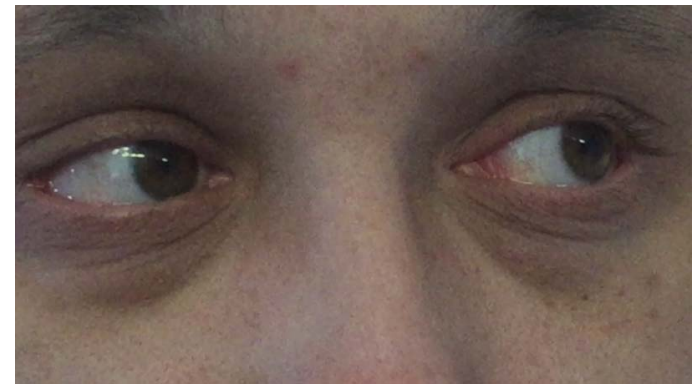

Video 1 Our patient demonstrates bilateral vertically upbeat nystagmus.

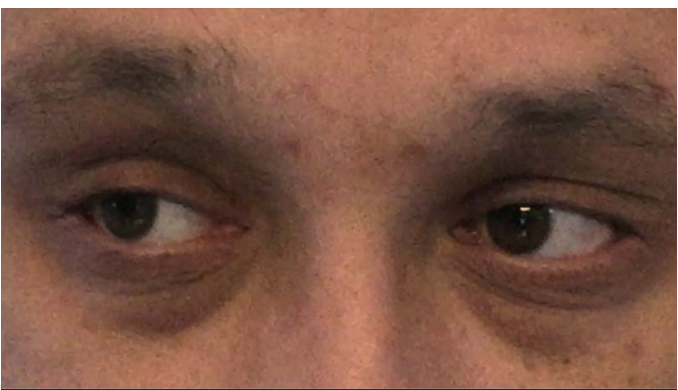

Video 2 Our patient's nystagmus has improved, although a few beats remain at extreme lateral gaze. whose activity is decreased in thiamine deficiency. Hypomagnesaemia may result in thiamine refractoriness in patients with Wernickes encephalopathy. ${ }^{2}$

Some studies have suggested that thiamine deficiency leads to Wernicke-Korsakoff syndrome only in patients whose transketolase has a reduced affinity for thiamine. ${ }^{3}$

Serum magnesium levels should always be checked in patients presenting with a history of excess alcohol who are at risk for developing Wernickes encephalopathy.

\section{Learning points}

- Patients with a history of excess alcohol often present with electrolyte abnormalities including hypomagnesaemia.

- Magnesium is an essential cofactor of transketolase, an enzyme whose activity is decreased in the context of thiamine deficiency.

- Magnesium levels should always be checked and supplemented if necessary in patients at risk of developing Wernickes encephalopathy.

Twitter Follow John Coughlan at @jjcoughl

Contributors JJC was primarily responsible for drafting the clinical case report. TM and MW assisted with preparation of clinical videos and collection of patient information. RL provided clinical guidance and gave editorial feedback. All authors contributed to preparation of this clinical case report.

Competing interests None declared.

Patient consent Obtained.

Provenance and peer review Not commissioned; externally peer reviewed.

\section{REFERENCES}

1 Sechi G, Serra A. Wernicke's encephalopathy: new clinical settings and recent advances in diagnosis and management. Lancet Neurol 2007:6:442-55.

2 Traviesa DC. Magnesium deficiency: a possible cause of thiamine refractoriness in Wernicke-Korsakoff encephalopathy. J Neurol Neurosurg Psychiatry 1974;37:959-62.

3 Blass JP, Gibson GE. Abnormality of a thiamine-requiring enzyme in patients with Wernicke-Korsakoff syndrome. N Engl J Med 1977;297:1367-70 
Copyright 2016 BMJ Publishing Group. All rights reserved. For permission to reuse any of this content visit http://group.bmj.com/group/rights-licensing/permissions.

BMJ Case Report Fellows may re-use this article for personal use and teaching without any further permission.

Become a Fellow of BMJ Case Reports today and you can:

- Submit as many cases as you like

- Enjoy fast sympathetic peer review and rapid publication of accepted articles

- Access all the published articles

- Re-use any of the published material for personal use and teaching without further permission

For information on Institutional Fellowships contact consortiasales@bmjgroup.com

Visit casereports.bmj.com for more articles like this and to become a Fellow 